\title{
New Mining Department at Armstrong College, Newcastle-on-Tyne.
}

ON May 14, H.R.H. the Prince of Wales opened the new Mining Department of Armstrong College. In his opening speech he said, "The industry is confronted with stern competition from overseas. It must be equipped to meet that competition, and I think it is generally agreed that it is to science that we must look in our distress. Science must show the way to an improvement in our methods, and scientific training must be available both for the leaders and the rank and file, so as to ensure that no single ounce of energy is lost in the tug-of-war against our competitors."

The demand that Armstrong College should intensify and enlarge its share of work of scientific research in the interests of the coalfields it mainly serves has recently become specific. The coal owners of Durham and Cumberland, the Federation of Iron and Steel Manufacturers, the Department of Scientific and Industrial Research and the coke and gas industries, have co-operated with the College in the formation of a committee to supervise and encourage the prosecution of researches bearing directly on their respective industries. This work is now well in hand; valuable reports have already been issued, and more may be confidently expected in the near future. Similar co-operation between the College and the Fuel Research Board has begun: a physical and chemical survey of the coal seams in the northern coalfields is in progress, the chief purpose being to obtain an exact knowledge of the properties of these seams. This work is being carried out at present in temporary buildings, but it will shortly be transferred to the top floor of the new building.

The Department of Mining in Armstrong College has long and fine traditions behind it. It forms the oldest mining school in Great Britain, for it dates back in one form or another to the year 1837. Many of the foremost men in the mining industry to-day received their training in it. The present head of the Department is Prof. Granville Poole, who has designed the new building which now provides adequate facilities for the teaching of mining and the prosecution of research.

The erection of this building has been made possible only by generous grants from the Miners' Welfare Fund. The sum of $£ 20,000$ was subscribed by the Central Committee of the Fund and $£ 10,000$ from the Northumberland District Committee. Anonymous donors have contributed nearly $£ 5000$ to the equipment of the building and a further sum of $£ 15,000$ is required. The building will occupy a central position when the general scheme for the development of the College is completed. The architect is Mr. Dunbar Smith, of London, who was also the architect for the new College Library and for the National Museum of Wales, one of the noblest buildings erected in Great Britain within recent years.

Apart from the rooms set apart for research, the Department has several prominent features; for example, an exhibition hall containing plant and models of great educational value, and products from modern carbonising and hydrogenating plants, etc., also a specially equipped laboratory housing plant for the dressing of minerals.

The courses of the Department are arranged to meet the requirements of those who wish to specialise in any branch of mining, and the diploma and degrees obtainable are accepted by the Board for Mining Examinations in lieu of two years' practical experience in a mine.

\section{Insect Nutrition and Metabolism.}

$\mathrm{T}$ $\mathrm{E}$ subject of nutrition and metabolism in insects is highly important, in that its adequate explora. tion is likely to provide fresh viewpoints for problems of insect control. At the same time its relation to such insect products as silk, lac, honey, and wax should not be overlooked. At the present time, knowledge of the metabolic processes of insects is limited to scattered experiments and observations, usually confined to individual species, and of too inadequate a character to admit of reliable generalisations being made. The literature is very extensive and, for that reason, imparts the impression that a large amount of work has already been accomplished. A survey of any small branch in this field will, however, reveal how much of the available information is of a comparatively trivial or incomplete character, and what an infinitesimal amount of really fundamental knowledge has, so far, been gained.

In the Transactions of the Entomological Society of London, 1928, Part 2, Mr. B. P. Uvarov, senior assistant in the Imperial Bureau of Entomology, has brought together the results of all the work done on the subject of insect nutrition and metabolism. His memoir takes the form of an admirable introductory survey $(65 \mathrm{pp}$.) of the range of problems involved, together with a bibliography of nearly six hundred titles. In the collation and examination of so large a mass of literature, the author has done a substantial service to entomology and laid the basis and provided a guide for future research.

If one selects, for example, the enzymes involved in the digestive processes of insects, rather a surprising amount of data will be found available, but much of the material is the result of old, or of imperfect, methods of technique. There is also the fact that the part played by micro-organisms living in the digestive tract further complicates the subject. The need for clearly ascertaining which enzymes are produced by the insect and which by micro-organisms of symbiotic or other relationship is abundantly evident. With plant-sucking insects we have evidence that they are capable of converting starch into sugars, but we know nothing concerning their utilisation of the protein constituents of cell sap. Buchner went so far as to conclude that the symbiotic microorganisms of aphids, coccids, etc., are able to utilise atmospheric nitrogen and so make up for a supposed deficiency in nitrogen absorbed by such insects from their plant hosts. It is, however, abundantly clear that there is no positive evidence indicating that sucking insects do not obtain and utilise all the nitrogen they need from the cell contents: we have to admit that the rôle of the symbionts is still unsettled.

Again, the problem of cellulose digestion in insects is very far from being settled in spite of the existence of tens of thousands of plant-feeding species. The presence of a cellulase has been found in very few insects and, for the vast majority of species, it would appear probable that, if cellulose is digested at all, it is by the intervention of micro-organisms, as has been so well demonstrated by Cleveland in the case 